\title{
Synergistic Effect of Turmeric (Curcuma longa), Galanga (Alpinia galanga) Powder and Lemongrass (Cymbopogon citratus) Essential oil as Natural Preservative in Chilled Storage of White Hard Clam (Meretrix lyrata)
}

\author{
MINH PHUOC NGUYEN \\ Faculty of Biotechnology, Ho Chi Minh City Open University, Ho Chi Minh City, Vietnam. \\ ${ }^{\star}$ Corresponding author E-mail: minh.np@ou.edu.vn \\ http://dx.doi.org/10.13005/ojc/360126 \\ (Received: December 10, 2019; Accepted: February 15, 2020)

\begin{abstract}
Turmeric (Curcuma longa) is an essential spice and highly regarded in herbal medicine with multifunctional activities. Galanga (Alpinia galanga) is highly evaluated as its specific flavor and aroma as well as plenty healthy effects. Lemongrass (Cymbopogon citratus) Essential oil has active chemical constituents with various therapeutic properties. White hard clam (Meretrix lyrata) is one of molluscs (bivalve) with economical value. However, it is highly perishable due to microbiological growth, enzymatic degradation and lipid oxidation. In order to preserve quality and extend shelf life of this valuable seafood, there was an attempt to investigate a combination of natural preservatives such as tumeric $(0.5 \%, 0.75 \%, 1.0 \%, 1.25 \%, 1.5 \%)$, galangal powder $(0.5 \%, 0.75 \%, 1.0 \%, 1.25 \%, 1.5 \%)$ and lemongrass essential oil $(0.5 \%, 0.75 \%, 1.0 \%)$ to create a synergistic antimicrobial effect. Results of this finding revealed that a combination of Turmeric powder \%: Galanga powder \% : Lemongrass essential oil \% (0.5\%: 0.5\%: $0.75 \%$ ) could prohibit bacterial proliferation ( $\left.1.31 \times 10^{4} \mathrm{cfu} / \mathrm{g}\right)$, maintain firmness $(1635.1 \mathrm{~N})$ and overal acceptability (8.57) during 12 days of chilled storage.
\end{abstract}

Keywords: Turmeric, Galanga, Lemongrass, White hard clam, Synergistic.

\section{INTRODUCTION}

Extracts from plants and herbs containing bioactive compounds have shown remarkable antioxidant and antimicrobial activities ${ }^{1}$. Turmeric (Curcuma longa) is one of the most useful herbal medicinal plants with a wide spectrum of pharmacological activities due to curcumin. It has various useful properties with antioxidant activities; against gastrointestinal disorder, inflammation, ulcer, cancer, fungal, microbial renal and hepatoprotective ${ }^{2}$. Galangal (Alpinia galanga) is also one medicinally important herb. The plant bears underground stems called rhizomes which have a strong aromatic aroma. Its rhizome is used as a spice and a source of essential $\mathrm{oil}^{3}$. Alpinia galanga rhizomes contained flavonoids and volatile oils possed different pharmacological effects ${ }^{4}$. Lemongrass (Cymbopogon citratus) is a perennial tropical grass with thin, long leaves and is one of the main medicinal and aromatic

This is an Open Access article licensed under a Creative Commons license: Attribution 4.0 International (CC- BY). Published by Oriental Scientific Publishing Company @ 2018 
plants. Its essential oil is often used as fragrances, flavors, perfumery, cosmetics, detergents, and pharmaceuticals ${ }^{5,6}$. Various chemical compounds in lemongrass essential oil possess antibacterial, antifungal, analgesic and mosquito repellent properties ${ }^{7,8,9,10}$. White hard clam (Meretrix lyrata) contained a large amount of essential amino acids, polyunsaturated fatty acids with high level of DHA and EPA, It is also an excellent source of macro and micro minerals ${ }^{11}$. It is highly perishable seafood due to microbiological growth, enzymatic degradation and lipid oxidation.

There were several researches mentioned to application of turmeric, galangal powder and lemongrass essential oil in seafood storage. Quality changes of sea bass slices wrapped with gelatin film incorporated with lemongrass essential oil were verified ${ }^{12}$. The effect of turmeric on shelf life extension of shrimp Penaeus semisulcatus under chilled storage conditions was investigated ${ }^{13}$. Protective effect of sodium chloride and turmeric on physicochemical characteristics of sun-dried Tengra fish was examined ${ }^{14}$. Galanga (Alpinia galanga) was utilized to the pickled-shrimp fermentation ${ }^{15}$. Turmeric, galangal powder and lemongrass are all valuable herbs with multifunctional attributes. Seafoods are extremely perishable and susceptible to both chemical and microbiological spoilage during processing or storage ${ }^{16}$. Objective of our study focused on the synergistic effect of turmeric, galangal powder and lemongrass essential oil in chilled storage of white hard clam muscle.

\section{MATERIALS AND METHODS}

\section{Material}

Turmeric and galanga rhizomes were collected from Hau Giang province, Vietnam. They were dried and milled into powder. Lemongrass essential oil was supplied from Rainbow Technique Trading Co. Ltd, Ho Chi Minh City, Vietnam. White hard clams (Meretrix lyrata) were harvested from Ben Tre province, Vietnam. They were conveyed on ice and thoroughly washed with clean water before moving to laboratory as quickly as possible for experiments. 3M-Petrifilm plates were originated from Van Dai Phat Co. Ltd, Ho Chi Minh City, Vietnam.

\section{Researching procedure}

White hard clams (Meretrix lyrata) with the same size were selected for experiments. Cooking white hard clams (Meretrix lyrata) could remove meat of from shells easily. White hard clam meat was then treated with turmeric, galanga powder and lemongrass esssential oil in different concentration to demonstrate their effects on physico-chemical, microbial and sensory characteristics during chilled storage. White hard clam meat was dipped in treatment solution for $15 \mathrm{~min}$. at $28^{\circ} \mathrm{C}$. Then it was dripped in $5 \mathrm{~min}$. packed in polyethylene bags, stored in cool store at $4^{\circ} \mathrm{C}$ for 12 days. After that, samples were analyzed the firmness $(\mathrm{N})$, total plate count $(\mathrm{cfu} / \mathrm{g})$, sensory score.

\section{Physico-chemical, sensory and statistical analysis}

Hardness ( $\mathrm{N}$ ) was evaluated by texture analyzer. Total plate count (cfu/g) was quantified by $3 \mathrm{M}$-Petrifilm. Sensory score was evaluated by a group of panelist using 9 point-Hedonic scale. The experiments were run in triplicate with three different lots of samples. Statistical analysis was performed by the Statgraphics Centurion XVI.

\section{RESULTS AND DISCUSSIONS}

\section{Effectiveness of turmeric powder (\%) and lemongrass essential oil (\%) on physico-chemical, microbial and organoleptic attributes of chilled white hard clam in 12 days of storage}

Texture is a very important variable reflecting the seafood quality. Texture changes are due to loss of moisture-holding capacity and the emission of insoluble aggregates during cool storage. The negative effect of loss in texture leads to toughening, dry, stringy and hard to chew ${ }^{17,18}$. During preservation, muscle components that are responsible for changes in seafood hardness are myofbrillar and connective tissue proteins which undergo degradation by proteases-primarily calpains, cathepsins and collagenases. These enzymes cause myofibril fragility and gaping, thus leading to decrease in hardness value ${ }^{19,20}$. Lipid oxidation and enzymatic activity are also responsible for softening and mushiness in seafood leading to degradation of overal acceptability ${ }^{21}$. Total plate count (cfu/g) is the common method to determine the microbial spoilage of foodstuff. The turmeric treatment significantly reduced bacterial growth than that treated with salt ${ }^{22}$. 
In our current research, different concentrations of turmeric powder $(0.5 \%, 0.75 \%$, $1.0 \%, 1.25 \%, 1.5 \%$ ) combined with lemongrass essential oil $0.5 \%$ were examined on white hard clam muscle during 12 days of chilled storage. Texture hardness $(\mathrm{N})$, total plate count $(\mathrm{cfu} / \mathrm{g})$ and organoleptic attributes of white hard clam muscle were revealed in Table 1. It's obviously noticed that $1.0 \%$ turmeric powder combined with $0.5 \%$ lemongrass essential oil could effectively maintain physico-chemical, microbial and sensory characteristics of white hard clam muscle.

Table 1: Effectiveness of turmeric powder (\%) and lemongrass essential oil (\%) on physico-chemical, microbial and organoleptic attributes of chilled white hard clam in 12 days of storage

\begin{tabular}{cccccc}
\hline Turmeric powder \%: & $0.5 \%$ : & $0.75 \%:$ & $1.0 \%:$ & $1.25 \%:$ & $\begin{array}{c}1.5 \%: \\
0.50 \%\end{array}$ \\
Lemongrass essential oil \% & $0.50 \%$ & $0.50 \%$ & $0.50 \%$ & $0.50 \%$ \\
\hline Texture hardness & 1429.1 & 1489.4 & 1521.3 & 1525.2 & 1529.1 \\
$(\mathrm{~N})$ & $\pm 121.3^{\mathrm{b}}$ & $\pm 112.9^{\mathrm{ab}}$ & $\pm 215.8^{\mathrm{a}}$ & $\pm 117.3^{\mathrm{a}}$ & $\pm 102.5^{\mathrm{a}}$ \\
Total plate count (10 $\mathrm{cfu} / \mathrm{g})$ & 6.24 & 4.79 & 4.41 & 4.03 & 2.87 \\
Sensory score & $\pm 0.05^{\mathrm{a}}$ & $\pm 0.01^{\mathrm{b}}$ & $\pm 0.03 \mathrm{~b}^{\mathrm{c}}$ & $\pm 0.01^{\mathrm{c}}$ & $\pm 0.02^{\mathrm{d}}$ \\
& 6.75 & 7.12 & 7.58 & 7.62 & 7.65 \\
& $\pm 0.03^{\mathrm{c}}$ & $\pm 0.02^{\mathrm{b}}$ & $\pm 0.01^{\mathrm{ab}}$ & $\pm 0.03^{\mathrm{a}}$ & $\pm 0.00^{\mathrm{a}}$ \\
\hline
\end{tabular}

Note: the values were expressed as the mean of three repetitions; the same characters (denoted above), the difference between them was not significant $(\alpha=5 \%)$.

Extracts from turmeric combination with shallot extract $(1.5 \%$ each, $v / v)$ were demonstrated to maintain quality attributes of vacuum packaged rainbow trout during 20 days of frozen storage ${ }^{23}$. Preservative effects of lemongrass essential oil and turmeric were demonstrated to improve the quality and extend the shelf life of the treated seafood products $^{24}$. The application of turmeric in peeled shrimp stored in ice (1:1 ratio) extended its shelf-life up to 8 days $^{13}$. Turmeric treated sun-dried salted fish maintained biochemical values and sensory score at the end of 12 months ${ }^{14}$.

Effectiveness of galanga powder (\%) and lemongrass essential oil (\%) on physicochemical, microbial and organoleptic attributes of chilled white hard clam in $\mathbf{1 2}$ days of storage In our current research, different concentrations of galanga powder $(0.5 \%, 0.75 \%$, $1.0 \%, 1.25 \%, 1.5 \%$ ) combined with lemongrass essential oil $0.5 \%$ were examined on white hard clam muscle during 12 days of chilled storage. Texture hardness $(\mathrm{N})$, total plate count $(\mathrm{cfu} / \mathrm{g})$ and organoleptic attributes of white hard clam muscle were revealed in table 2. It's obviously noticed that $1.25 \%$ galanga powder combined with $0.5 \%$ lemongrass essential oil could effectively maintain physico-chemical, microbial and sensory characteristics of white hard clam muscle.

In another research, with $10 \%$ sliced galangal in shrimp mixture, the final galangalpickled shrimp had the good a pleasant taste and appearance $^{15}$.

Table 2: Effectiveness of galanga powder (\%) and lemongrass essential oil (\%) on physico-chemical, microbial and organoleptic attributes of chilled white hard clam in 12 days of storage

\begin{tabular}{cccccc}
\hline Galanga powder \%: & $0.5 \%:$ & $0.75 \%:$ & $1.0 \%:$ & $1.25 \%:$ & $1.5 \%:$ \\
Lemongrass essential oil \% & $0.50 \%$ & $0.50 \%$ & $0.50 \%$ & $0.50 \%$ & $0.50 \%$ \\
\hline Texture hardness & 1407.2 & 1449.7 & 1485.9 & 1514.2 & 1520.4 \\
$(\mathrm{~N})$ & $\pm 105.9^{\mathrm{c}}$ & $\pm 203.6^{\mathrm{b}}$ & $\pm 94.2^{2 \mathrm{~b}}$ & $\pm 78.2^{\mathrm{a}}$ & $\pm 93.1^{\mathrm{a}}$ \\
Total plate count $\left(10^{4} \mathrm{cfu} / \mathrm{g}\right)$ & 7.85 & 5.42 & 4.19 & 3.84 & 3.41 \\
& $\pm 0.02^{\mathrm{a}}$ & $\pm 0.03^{\mathrm{b}}$ & $\pm 0.00^{\mathrm{c}}$ & $\pm 0.04^{\mathrm{cd}}$ & $\pm 0.00^{\mathrm{d}}$ \\
Sensory score & 6.41 & 6.94 & 7.12 & 7.67 & 7.84 \\
& $\pm 0.00^{\mathrm{c}}$ & $\pm 0.02^{\mathrm{bc}}$ & $\pm 0.01^{\mathrm{b}}$ & $\pm 0.03^{\mathrm{ab}}$ & $\pm 0.01^{\mathrm{a}}$ \\
\hline
\end{tabular}

Note: the values were expressed as the mean of three repetitions; the same characters (denoted above), the difference between them was not significant $(\alpha=5 \%)$. 
Synergistic effect of turmeric, galanga powder and lemongrass essential oil (\%) on physicochemical, microbial and organoleptic attributes of chilled white hard clam in $\mathbf{1 2}$ days of storage

Essential oil as an antimicrobial agent has positive effect on bacteria, while less is known about their action on yeast and molds ${ }^{25}$. It can be applied either to inhibit the bacterial growth (bacteriostatic) or to kill bacterial cells (bactericide). Gram-positive bacteria are slightly more susceptible to essential oil than Gram-negative ones ${ }^{26,27}$. The antimicrobial activity of essential oil can be attributed to mainly the phenolic constituents ${ }^{28,29}$. Essential oil also creates mechanisms in prevention of chain initiation, free-radical scavenging activity and retardation of lipid oxidation ${ }^{26,30,31}$.

In our current research, different formulations of turmeric: galanga powder: lemongrass essential oil (0.25\%: $0.75 \%$ : 0.5\%: 0.5\%: 0.5\%: 0.5\%: $0.75 \%$ : 0.25\%: 0.5\%: 0.5\%: 0.5\%, 0.75\%: 0.5\%: 0.5\%: $1.0 \%)$ were examined on white hard clam muscle during 12 days of chilled storage. Texture hardness $(\mathrm{N})$, total plate count (cfu/g) and organoleptic attributes of white hard clam muscle were revealed in Table 3. It's obviously noticed that turmeric: galanga powder: lemongrass essential oil (0.5\%: $0.5 \%: 0.75 \%$ ) could effectively maintain physico-chemical, microbial and sensory characteristics of white hard clam muscle.

Table 3: Synergistic effect of turmeric combined galanga powder (\%) and lemongrass essential oil (\%) on physico-chemical, microbial and organoleptic attributes of chilled white hard clam in 12 days of storage

\begin{tabular}{cccccc}
\hline Turmeric powder \%: & $0.25 \%:$ & $0.5 \%:$ & $0.75 \%:$ & $0.5 \%:$ & $0.5 \%:$ \\
Galanga powder \%: & $0.75 \%:$ & $0.5 \%:$ & $0.25 \%:$ & $0.5 \%:$ & $0.5 \%:$ \\
Lemongrass essential oil \% & $0.50 \%$ & $0.50 \%$ & $0.50 \%$ & $0.75 \%$ & $1.00 \%$ \\
\hline Texture hardness & 1544.8 & 1576.5 & 1593.2 & 1635.1 & 1641.6 \\
$(\mathrm{~N})$ & $\pm 115.3^{\mathrm{c}}$ & $\pm 63.1 \mathrm{~b}^{\mathrm{c}}$ & $\pm 112.4^{\mathrm{b}}$ & $\pm 39.5^{\mathrm{a}}$ & $\pm 23.7^{\mathrm{a}}$ \\
& 3.21 & 3.01 & 2.75 & 1.31 & 1.27 \\
Total plate count (104 cfu/g) & $\pm 0.02^{\mathrm{a}}$ & $\pm 0.03^{\mathrm{ab}}$ & $\pm 0.02^{\mathrm{b}}$ & $\pm 0.02^{\mathrm{c}}$ & $\pm 0.05^{\mathrm{d}}$ \\
& 7.85 & 7.98 & 8.34 & 8.57 & 8.76 \\
Sensory score & $\pm 0.03^{\mathrm{b}}$ & $\pm 0.02^{\mathrm{ab}}$ & $\pm 0.00^{\mathrm{ab}}$ & $\pm 0.02^{\mathrm{a}}$ & $\pm 0.03^{\mathrm{a}}$ \\
\hline
\end{tabular}

Note: the values were expressed as the mean of three repetitions; the same characters (denoted above), the difference between them was not significant $(\alpha=5 \%)$.

Supplementation of herbal extracts to ice improved the seafood quality during preservation ${ }^{32,33}$. The application of turmeric, galangal powder and lemongrass essential oil has great positive impact on preservation of white hard clam muscle as they maintained the organoleptic characteristics, texture firmness and reduced bacterial growth to some extent.

\section{CONCLUSION}

Successful application of turmeric, galanga powder and lemongrass essential oil treatments have been carried out on white hard clam muscle.
The combination of turmeric, galanga powder and lemongrass essential oil suppressed the degradation of raw white hard clam muscle as indicated by both microbiological and physicochemical characteristics.

\section{ACKNOWLEDGMENT}

This research did not receive any specific grant from funding agencies in the public, commercial, or not-for-profit sectors.

\section{Conflicts of Interest}

The authors declare no conflict of interest.

\section{REFERENCES}

1. Viji P.; Venkateshwarlu G.; Ravishankar C. N.; and Srinivasa Gopal T. K; Role of plant extracts as natural additives in fish and fish products-a review. Fishery Technology., 2017, 54, 145-154.

2. Hamid Nasri.; Najmeh Sahinfard.; Mortaza Rafieian.; Samira Rafieian.; Maryam Shirzad.;
Mahmoud Rafieian-kopaei.; Turmeric: A spice with multifunctional medicinal properties. Journal of HerbMed Pharmacology., 2014, 3, 5-8.

3. Anirban Chouni.; Santanu Paul.; A review on phytochemical and pharmacological potential of Alpinia galanga. Pharmacogn J., 2018, 10, 9-15. 
4. Pal Jain A.; Singh Pawara R.; Lodhia S.; Singhaia A.; Immunomodulatory and antioxidant potential of Alpinia galanga Linn. rhizomes. Pharmacogn Commun., 2012, 2, 30-37.

5. Abe S.; Sato Y.; Inoue S.; Ishibashi H.; Maruyama N.; Takizawa T.; Anti-Candida albicans activity of essential oils including Lemongrass (Cymbopogon citratus) oil and its component. Citral. Jap J Med Mycol., 2012, 44, 285-291.

6. Tyagi A. K.; Malik A.; Morphostructural damage in food-spoiling bacteria due to the Lemon grass oil and its vapor: SEM, TEM, and AFM investigations. Evid Based Complement Alternat Med., 2012, 69, 2625.

7. Negrelle R. R. B.; Gomes E. C.; Cymbopogon citratus DC. Stapf: chemical composition and biological activities. Rev Bras PI Med., 2007, 9, 80-92.

8. Silva C. D. B. D.; Guterres S. S.; Weisheimer V.; Schapoval E. E.; Antifungal activity of the Lemon grass oil and citral against Candida spp. Braz J Infect Dis., 2008, 12, 63-66.

9. Tyagi A. K.; Malik A. Liquid and vapor-phase antifungal activities of selected essential oils against Candida albicans: microscopic observations and chemical characterization of Cymbopogon citratus. BMC Complement Alternat Med., 2010, 10, 65.

10. Boukhatem M. N.; Kameli A.; Ferhat M. A.; Saidi F.; Tayebi K.; The food preservative potential of essential oils: is lemongrass the answer? J Verbr Lebensm., 2014, 9, 1321.

11. Karnjanapratum S.; Benjakul S.; Kishimura H.; Tsai YH.; Chemical compositions and nutritional value of Asian hard clam (Meretrix lusoria) from the coast of Andaman Sea. Food Chemistry., 2013, 141, 4138- 4145.

12. Ahmad M.; Benjakul S.; Sumpavapol P.; and Nirmal N. P.; Quality changes of sea bass slices wrapped with gelatin film incorporated with lemongrass essential oil. International Journal of Food Microbiology., 2012, 155, 171-178.

13. Prabhu N. M.; Rajasekar P.; Nisha R. G.; Yasminebegam A. A.; Kannapiran E.; Manikandan R.; Effect of turmeric on shrimp (Penaeus semisulcatus) shelf life extension in chilled storage conditions. Iranian Journal of Fisheries Sciences., 2015, 15, 39-52.
14. Farid F. B.; Latifa G. A.; Chakraborty S. C.; Nahid M. N and Begum M. Protective effect of Salt (sodium chloride) and Turmeric (Curcuma longa) on physicochemical attributes of sundried Tengra fish (Mystus tengra; HamiltonBuchanan, 1822) at Laboratory condition. International Research Journal of Biological Sciences., 2015, 4, 33-40.

15. Nguyen Phuoc Minh.; Pham Thi Le Pha.; Nguyen Hong Tham and Nguyen Thi Van Linh. Technical factors influencing to production of galangal-pickled shrimp (Litopenaeus Vannamei). Orient. J. Chem., 2019, 35, 442-448.

16. Abdo Hassoun.; Ozlem Emir Çoban.; Essential oils for antimicrobial and antioxidant applications in fish and other seafood products. Trends in Food Science \& Technology., 2017, 68, 26-36.

17. Medina I.; Gallardo J. M.; Aubourg S. P.; Quality preservation in chilled and frozen fsh products by employment of slurry ice and natural antioxidants-A review. International Journal of Food Science and Technology., 2009, 44, 1467-1479.

18. Arvanitoyannis I. S.; Tsitsika E. V.; Panagiotaki P. Implementation of quality control methods (physico-chemical, microbiological and sensory) in conjuction with multivariate analysis towads fsh authenticity-A review. International Journal of Food Science and Technology., 2005, 40, 237-263.

19. Yi J.; Zhang L.; Ding G.; Hu X.; Liao X.; Zhang Y.; High hydrostatic pressure and thermal treatments for ready-to-eat wine marinated shrimp: An evaluation of microbiological and physicochemical qualities. Innovative Food Science and Emerging Technology., 2013, 20, 16-23.

20. Wan Norhana Md Noordin.; Nannthini Shunmugam.; Nurul Huda and Frederick Adzitey. The effects of essential oils and organic acids on microbiological and physicochemical properties of whole shrimps at refrigerated storage. Current Research in Nutrition and Food Science., 2018, 6, 273-283.

21. Sundararajan S.; Prudente A.; Bankston D.; King J. M.; Wilson P.; Sathivel S. Evaluation of green tea extracts as a glazing material for shrimp frozen by cryogenic freezing. Journal of Food Science., 2011, 76, 511-517. 
22. Maruf Imtiaz.; Syed Ariful Haque.; Rajib Sarker.; Murad Mufty.; Mohammad Ali.; Shamim Parvez.; Shaheed Reza.; Simul Bhuyan and Aminur Rahman.; Quality assessment of improved sun dried ribbon fish (Trichiurus haumela) by salt and turmeric powder treatment. Int'l Journal of Advances in Chemical Engg., \& Biological Sciences., 2017, 4, 162-167.

23. Pezeshk S.; Rezaei M. and Hosseini H. Effect of turmeric, shallot extracts and their combinations on quality characteristics of vacuum packaged rainbow trout stored at $4 \pm 1^{\circ} \mathrm{C}$. J. Food Sci., 2011, 76, 387- 391.

24. Masniyom P.; Benjama O.; Maneesri J.; Effect of turmeric and lemongrass essential oils and their mixture on quality changes of refrigerated green mussel (Perna viridis). International Journal of Food Science and Technology., 2012, 47, 1079-1085.

25. Hyldgaard M.; Mygind T.; Meyer R. L. Essential oils in food preservation: Mode of action, synergies, and interactions with food matrix components. Frontiers in Microbiology., 2012, 3, 1-24.

26. Rodriguez-Garcia I.; Silva-Espinoza B. A.; Ortega-Ramirez L. A.; Leyva J. M.; Siddiqui M. W.; Cruz-Valenzuela M. R.; Ayala-Zavala J. F.; Oregano essential oil as an antimicrobial and antioxidant additive in food products. Critical Reviews in Food Science and Nutrition., 2016, 56, 1717-1727.

27. Tongnuanchan P.; Benjakul S.; Essential oils: Extraction, bioactivities, and their uses for food preservation. Journal of Food Science., 2014, 79, 1-19.

28. Jayasena D. D.; Jo C. Potential application of essential oils as natural antioxidants in meat and meat products: A review. Food Reviews International 2014, 30, 71-90.

29. Perricone M.; Arace E.; Corbo M. R.; Sinigaglia M.; Bevilacqua A. Bioactivity of essential oils: A review on their interaction with food components. Frontiers in Microbiology., 2015, 6, 1-7.

30. Maqsood S.; Benjakul S.; Abushelaibi A.; Alam A. Phenolic compounds and plant phenolic extracts as natural antioxidants in prevention of lipid oxidation in seafood: A detailed review. Comprehensive Reviews in Food Science and Food Safety., 2014, 13, 1125-1140.

31. Maqsood S.; Benjakul S.; Shahidi F.; Emerging role of phenolic compounds as natural food additives in fish and fish products. Critical Reviews in Food Science and Nutrition., 2012, 53, 162-179.

32. Quitral V.; Donoso M. L.; Ortiz J.; Herrera M. V.; Araya H.; Aubourg S. P.; Chemical changes during the chilled storage of Chilean jack mackerel (Trachurus murphyi): Effect of a plant-extract icing system. LWT Food Sci. Technol., 2009, 42, 1450-1454.

33. Ozyurt G.; Kuley E.; Balikci E.; Kacar C.; Gokdogan S. and Etyemez M. Effect of the icing with rosemary extract on the oxidative stability and biogenic amine formation in sardine (Sardinella aurita) during chilled storage. Food and Bioprocess Tech., 2012, 5, 2777-2786. 